\title{
DEVELOPMENT AND METHODOLOGY FOR THE ESTIMATION OF LISINOPRIL AND ATORVASTATIN IN PHARMACEUTICALS
}

\footnotetext{
Introduction. The cause of hypertension and coronary heart disease in most cases is hypercholesterolemia. Therefore, for the treatment and prevention of most pharmacotherapy regimens, antiatherosclerotic drugs are used. With a high class of recommendations and level of evidence, high efficiency for primary and secondary prevention of coronary heart disease, statins are widely used in clinical practice.

The aim of the study - to improve more rapid, simple, selective, less expensive methods of thin layer chromatography analysis of simultaneous determination of lisinopril and atorvastatin in pharmaceuticals.

Research Methods. The present study assessed mobile phases of lisinopril and atorvastatin for TLC.

Results and Discussion. Thin layer chromatography can be used to: monitor the progress of a reaction, identify compounds, determine the purity of a substance. Method of simultaneous identification of lisinopril and atorvastatin by TLC was developed. We investigated different mobile phases to optimize the development of analytical methods of lisinopril and atorvastatin by TLC. It was established that the most optimal Rf observed using mobile phase ammonia $R(25 \%)$ - propanol $R(30: 70, \mathrm{v} / \mathrm{v})$. We explored the validation characteristics - specificity and suitability of the chromatographic system that met, the eligibility criteria established by the SPhU.

Conclusions. We developed chromatographic method for simultaneous determination of lisinopril and atorvastatin. Propects for future research will be aimed at developing analytical methods of analysis.
}

KEY WORDS: lisinopril and atorvastatin; identification; thin layer chromatography; validation.

INTRODUCTION. Hypertension is the most common non-communicable disease, which is accompanied by high mortality rate among people of working age and their disability from cardiovascular and cerebrovascular diseases. According to standardized protocols for the treatment of hypertension, antihypertensive drugs of 5 main classes - first-line drugs are most often used, which when using in equivalent doses help to lower blood pressure and significantly reduce the risk of cardiovascular complications. Quite often doctors prescribe two/three drugs at the same time, which reduces compliance with pharmacotherapy due to the risk of violation of the drug regimen. The cause of hypertension and coronary heart disease in most cases is hypercholesterolemia. Therefore, for the treatment and prevention of most pharmacotherapy regimens, antiatherosclerotic drugs are used. With a high class of recommendations and level of evidence, high efficiency for primary and secondary prevention of coronary heart disease, statins are widely used in clinical practice [1].

The aim of the present study was to improve to more rapid, simple, selective, less expensive me(c) D. B. Koval, N. S. Shulyak, L. S. Logoyda, 2020. thods TLC analysis of simultaneous determination of lisinopril and atorvastatin in pharmaceuticals.

\section{RESEARCH METHODS.}

Chemicals and reagents

Atorvastatin calcium (purity $99.1 \%$, as determined by HPLC) was purchased from the National Institute for the Control of Pharmaceutical and Biological Products (NICPB, Beijing, PR China), lisinopril (purity $98.9 \%$ ) was purchased from SigmaAldrich (Switzerland). Atorvastatin $10 \mathrm{mg}$ tablets and Lisinopril $10 \mathrm{mg}$ tablets were purchased from local pharmacy. All solvents used in experiments was HPLC gradient grade.

Analytical equipment

Analytical Balance Mettler Toledo MPC227, Scales AVT-120-5D, measuring vessel glass and reagents that meet the SPhU requirements.

TLC test was carried out using Silica gel, chromatographic plates 60 F254 "Merck" (Germany) and "Sorbfil" (Russia).

Sample preparation for investigation solution.

Investigation solution from tablets lisinopril and atorvastatin. To sample powder tablets or powder, equivalent to $10.00 \mathrm{mg}$ lisinopril, $10.00 \mathrm{mg}$ atorvas- 
tatin add $5.0 \mathrm{ml}$ of methanol $R$ and dilute with methanol $R$ to $10.0 \mathrm{ml}$, mix and filter.

Reference solution of lisinopril. $10.00 \mathrm{mg}$ Pharmacopoeial standard sample of lisinopril dissolved in methanol $R$ and dilute with the same solvent to $10.0 \mathrm{ml}$.

Reference solution of atorvastatin. $10.00 \mathrm{mg}$ Pharmacopoeial standard sample of atorvastatin dissolved in methanol $R$ and dilute with the same solvent to $10.0 \mathrm{ml}$.

Mobile phase: ammonia (25\%) R-propanol $R$ $(30: 70, v / v)$.

Samples that are applied: $5 \mu \mathrm{l}$, applied the test solutions and investigation solutions.

Over a path of $10 \mathrm{~cm}$ from the starting line.

Detection: The spots are visualized by spraying with Dragendorff reagent.

RESULTS AND DISCUSSION. Thin layer chromatography can be used to: Monitor the progress of a reaction, identify compounds present in a given substance, determine the purity of a substance. Separation of compounds is based on the competition of the solute and the mobile phase for binding places on the stationary phase. For instance, if normal phase silica gel is used as the stationary phase it can be considered polar. Given two compounds which differ in polarity, the more polar compound has a stronger interaction with the silica and is therefore more capable to dispel the mobile phase from the binding places. As the mobile phase moves pass the surface of the silica gel it transports the analyte pass the particles of the stationary phase. However, the analyte molecules are only free to move with the solvent if they are not bound to the surface of the silica gel. Thus, the fraction of the time that the analyte is bound to the surface of the silica gel relative to the time it spends in solution determines the retention factor of the analyte. The ability of an analyte to bind to the surface of the silica gel in the presence of a particular solvent or mixture of solvents can be viewed as a the sum of two competitive interactions. First, polar groups in the solvent can compete with the analyte for binding sites on the surface of the silica gel. Therefore, if a highly polar solvent is used, it will interact strongly with the surface of the silica gel and will leave few sites on the stationary phase free to bind with the analyte. The analyte will, therefore, move quickly pass the stationary phase. Similarly, polar groups in the solvent can interact strongly with polar functionality in the analyte and prevent interaction of the analyte with the surface of the silica gel [2].

The present study was assessed the different solvent extracts of lisinopril and atorvastatin for TLC [3-11]. The chromatograms obtained with the test solution were detected at the main spot basic substance in the chromatograms obtained with reference solutions, corresponding in size and color. We investigated different mobile phases to optimize the development of analytical methods of lisinopril and atorvastatin by TLC. The factors of mobility in the studied of simultaneous determination of lisinopril and atorvastatin in mobile phases, are listed in Table.

We established that the most optimal Rf observed using mobile phases for simultaneous determination of lisinopril and atorvastatin: ammonia $R(25 \%)$ - propanol $R$ (30:70).

The analysis considered probable, though the test requirements "Check suitability chromatographic system".

According to the SPhU and Note for guidance on validation of analytical procedures: text and methodology (CPMP/ICH/381/95) to test the Identification must be validated, to determine such characteristics as specificity and suitability of the chromatographic system. The maximum difference of Rf values in the same plate (for two series of plates) must not exceed the value of 0.02 . Originally, plates were tested according to the requirements of SPhU on chromatographic resolution. When checking for the stability of the solution at the time we started chromatography of lisinopril and atorvastatin freshly prepared test solution sustained, over time for $30 \mathrm{~min}$. Visual assessment of spots on the size and intensity of staining confirms that they clearly appear as freshly cooked and seasoned in time solutions (for plates of different series). The

Table - Chromatographic characteristics of lisinopril and atorvastatin in different mobile phases

\begin{tabular}{|c|c|c|c|c|}
\hline Mobile phase & $\begin{array}{c}\text { Stationary phase } \\
\text { (plate) } \\
\text { Rf on "Sorbfil" } \\
\text { (lisinopril) }\end{array}$ & $\begin{array}{c}\text { Stationary phase } \\
\text { (plate) } \\
\text { Rf on "Sorbfil" } \\
\text { (atorvastatin) }\end{array}$ & $\begin{array}{l}\text { The limit } \\
\text { of detection } \\
\text { of lisinopril, } \\
\text { micrograms }\end{array}$ & $\begin{array}{c}\text { The limit } \\
\text { of detection } \\
\text { of atorvastatin, } \\
\text { micrograms }\end{array}$ \\
\hline $\begin{array}{l}\text { chloroform R-methanol R- } \\
\text { ammonia (25 \%) R (4: 4: 2) }\end{array}$ & 0.61 & 0.85 & 0.4 & 0.4 \\
\hline $\begin{array}{l}\text { ammonia (25 \%) R- } \\
\text { propanol R (30: 70) }\end{array}$ & 0.17 & 0.48 & 0.4 & 0.4 \\
\hline $\begin{array}{l}\text { n-butanol R-acetic acid } \\
\text { R-water R (40: 10: 20) }\end{array}$ & 0.19 & 0.82 & 0.4 & 0.4 \\
\hline acetone R-water R ( 3: 2) & 0.75 & 0.1 & 0.4 & 0.4 \\
\hline
\end{tabular}


solutions were stable over time and new areas, had been identified.

Thus, we explored the validation characteristics specificity and suitability of the chromatographic system that met, the eligibility criteria established by the SPhU $[12,13]$. Therefore, the present study provided a suitable as well as accurate method for simultaneous determination of lisinopril and atorvastatin, which is of potential practical significance in development of analytical methods.
CONCLUSIONS. We developed TLC method for simultaneous determination of lisinopril and atorvastatin. We found that the most optimal Rf observed using mobile phases for simultaneous determination of lisinopril and atorvastatin: ammonia $R(25 \%)$ - propanol $R$ (30:70). The validation study of the characteristics of specificity and suitability of the chromatographic system, confirmed that they meet the eligibility requirements under the SPhU. Propects for future research will be aimed at developing analytical methods of analysis of lisinopril and atorvastatin.

7. Chatwal G. R. Instrumental methods of chemical analysis. 5th edn. / G. R. G. R. Chatwal, S. K. Anand. Himalaya publishing house, 2008. - 2. - P. 599-616.

8. Beckett A. H. Practical pharmaceutical chemistry. Thin layer chromatography / A. H. Beckett, J. B. Stenlake. - CBS publishers. 4th edn. - 2005. - P. 115-128.

9. Ali M. Thin-layer chromatography of aromatic amines / M. Ali, V. Agrawal // Separ. Sci. Technol. -2002. 37. - P. 363-377.

10. Sharma B. K. Instrumental methods of chemical analysis / B. K. Sharma. - Meerut: Goel publishing house. 5th ed. - 2007. - P. 241-264.

11. Logoyda L. Development and methodology for the estimation of bisoprolol in pharmaceuticals / L. Logoyda // Med. Clin. Chem. - 2017. - No. 2. - P. 34-37.

12. ICH Topic. Q2 (R1) Validation of Analytical Procedures: Text and methodology.

13. Sagar V. Instrumental methods of drug analysis / V. Sagar. - Pharma Med. Press. 1st edn. - 2009. $263 \mathrm{p}$.

\section{REFERENCES}

1. Lippi, G., Mattiuzzi, C., \& Cervellin, G. (2019). Statins popularity: A Global picture to statins. Br. J. Clin. Pharmacol., 85, 1614-1615. Retrieved from: https://doi. org/10.1111/bcp.13944

2. Bele, A.A., \& Khale, A. (2011). An overview on thin layer chromatography. Int. J. Pharm. Sci. Res., 2 (2), 256-267.

3. Singhal, S., Singhal, N., \& Agarwal, S. (2009). Pharmaceutical analysis II. Thin layer chromatography. Pragati prakashan. 1st edn.

4. Kasture, A.V., Mahadik, K.R., Wadodkar, S.G., \& More, H.N. (2005). A textbook of pharmaceutical analysis. Instrumental methods. Nirali Prakashan. 9th edn.

5. Quach, H.T., Steeper, R.L., \& Griffin, G.W. (2004). Separation of plant pigments by thin layer chromatography. J. Chem. Educ., 81, 385-387.

6. Skoog, D.A., Holler, F.J., \& Nieman, T.A. (2006). Principles of instrumental analysis. Saunders college publishing. 5th edn.
7. Chatwal, G.R., \&Anand, S.K. (2008). Instrumental methods of chemical analysis. Himalaya publishing house. 5th edn.

8. Beckett, A.H., \& Stenlake, J.B. (2005). Practical pharmaceutical chemistry. Thin layer chromatography. CBS publishers. 4th edn.

9. Ali, M., \& Agrawal, V. (2002). Thin-layer chromatography of aromatic amines. Separ. Sci. Technol., 37, 363-377.

10. Sharma, B.K. (2007). Instrumental methods of chemical analysis. Meerut: Goel publishing house. 5th edn., pp. 241-264.

11. Logoyda, L. (2017). Development and methodology for the estimation of bisoprolol in pharmaceuticals. Med. Clin. Chem., 2, 34-37.

12. ICH Topic. Q2 (R1) Validation of Analytical Procedures: Text and methodology.

13. Sagar, V. (2009). Instrumental methods of drug analysis. Pharma Med. Press. 1st edn. 


\section{РОЗРОБКА І МЕТОДОЛОГІЯ ВИЗНАЧЕННЯ ЛІЗИНОПРИЛУ ТА АТОРВАСТАТИНУ В ЛІКАРСЬКИХ ЗАСОБАХ}

\section{Резюме}

Вступ. Розвиток артеріальної гіпертензії та ішемічної хвороби серця в більшості випадків спричиняє гіперхолестеринемія. Тому з метою лікування та профрілактики в більшості схем фрармакотерапії застосовують антиатеросклеротичні лікарські засоби. Статини мають високий клас рекомендацій та рівень доказовості, високу ефективність для первинної і вторинної профрілактики ішемічної хвороби серця, тому їх широко використовують у клінічній практичі.

Мета дослідження - вдосконалити більш швидкі, прості, селективні й менш дорогі методи тонкошарової хроматографрії ля одночасного визначення лізиноприлу та аторвастатину в лікарських засобах.

Методи дослідження. У цьому дослідженні оцінювали рухомі фрази з метою одночасного визначення лізиноприлу та аторвастатину для тонкошарової хроматографії.

Результати й обговорення. Тонкошарова хроматографрія може бути використана для моніторингу прогресу реакції, ідентифрікації лікарських речовин, визначення чистоти речовин. Ми розробили методику одночасної ідентифрікації лізиноприлу та аторвастатину за допомогою тонкошарової хроматографрії, а також досліджували різні рухомі фрази, щоб оптимізувати розробку аналітичної методики лізиноприлу й аторвастатину методом тонкошарової хроматографії. Встановлено, що найбільш оптимальна $R f$ спостерігається при використанні розчину аміаку $P(25 \%)$ - пропанолу P (30:70, v/v). Було вивчено характеристики валідації-специфрічність та придатність хроматографрічної системи, що відповідала критеріям прийнятності, встановленим ДФу.

Висновок. Розроблено хроматографрічну методику одночасного визначення лізиноприлу та аторвастатину. Майбутні дослідження буде спрямовано на розробку аналітичних методів аналізу.

КЛЮЧОВІ СЛОВА: лізиноприл; аторвастатин; ідентифікація; тонкошарова хроматографія; валідація.

Д. Б. Коваль ${ }^{2}$ Н. С. Шуляк' ВОЛЫНСКИЙ МЕДИЦИНСКИЙ ИНСТИТУТ ${ }^{1}$, ЛУЦК ТЕРНОПОЛЬСКИЙ НАЦИОНАЛЬНЫЙ МЕДИЦИНСКИЙ УНИВЕРСИТЕТ ИМЕНИ И. Я. ГОРБАЧЕВСКОГО МОЗ УКРАИНЫ ${ }^{2}$

\section{РАЗРАБОТКА И МЕТОДОЛОГИЯ ОПРЕДЕЛЕНИЯ ЛИЗИНОПРИЛА И АТОРВАСТАТИНА В ЛЕКАРСТВЕННЫХ СРЕДСТВАХ}

\section{Резюме}

Вступление. Причиной артериальной гипертензии и ишемической болезни сердца в большинстве случаев является гиперхолестеринемия. Поэтому с целью лечения и профилактики в большинстве схем фрармакотерапии применяют антиатеросклеротические лекарственные средства. Статины имеют высокий класс рекомендаций и уровень доказательности, высокую эфффективность для первичной и вторичной профилактики ишемической болезни сердца, поэтому их широко используют в клинической практике.

Цель исследования - усовершенствовать более быстрые, простые, селективные и менее дорогостоящие методы тонкослойной хроматографии для одновременного определения лизиноприла и аторвастатина в лекарственных средствах.

Методы исследования. В этом исследовании оценивали подвижные фразы с целью одновременного определения лизиноприла и аторвастатина для тонкослойной хроматографии.

Результати и обсуждение. Тонкослойная хроматография может быть использована для мониторинга прогресса реакции, идентификации лекарственных веществ, определения чистоты веществ. Мы разработали методику одновременной идентификации лизиноприла и аторвастатина с помощью тон- 
кослойной хроматографрии, а также исследовали различные подвижные фразы, чтобы оптимизировать разработку аналитической методики лизиноприла и аторвастатина методом тонкослойной хроматографии. Установлено, что наиболее оптимальная $R f$ наблюдается при использовании раствора амиака P (25 \%) - пропанола P (30:70, v/v). Было изучено характеристики валидации - специфичность и пригодность хроматографической системы, которая соответствовала критериям отбора, установленным ГФу.

Вывод. Разработана хроматографическая методика одновременного определения лизиноприла и аторвастатина. Будущие исследования будут направлены на разработку аналитических методов анализа.

КЛЮЧЕВЫЕ СЛОВА: лизиноприл; аторвастатин; идентификация; тонкослойная хроматографрия; валидация.

Received 04.08.20

Address for correspondence: L. S. Logoyda, I. Horbachevsky Ternopil National Medical University, Maidan Voli, 1, Ternopil, 46001, Ukraine, e-mail: logojda@tdmu.edu.ua. 